\title{
ESSENTIAL REFERENCE
}

\section{The Cambridge Thesaurus of American English \\ William D. Lutz}

An original and up-to-date collection of over 200,000 synonyms and antonyms for the most commonly used words and phrases in contemporary American English. The Thesaurus is alphabetically arranged, and designed to give the user quick access to a coherent set of synonyms and antonyms.

1994500 pp. 41427-X Hardcover $\$ 16.95$

\section{Fifty Years Among the New Words}

A Dictionary of Neologisms, 1941-1991

\section{Edited by John Algeo}

"All those interested in the development of the English language owe John Algeo and the Cambridge University Press a debt of gratitude for providing such a valuable resource."

-Henry J. Ricardo, American Reference Books Annual

"An amazing work..."

- Verbatim

1993272 pp. $44971-5$ Paperback $\$ 24.95$

\section{Cambridge Paperback Encyclopedia Edited by David Crystal}

The quintessential paperback reference. Nearly 20,000 easy-to-read entries contain essential information for the 1990 s on myriad topics, including technology, the environment, sports, politics, literature, history, art, music, medicine, geography, and much more.

1993271 pp. $43762-8$ Paperback $\$ 19.95$

Available in bookstores or from

\section{West 20th Street, NY, NY 10011-4211.}

CAMBRIDGE

Cali toll free 800-872-7423.

UNIVERSITY PRESS MasterCard/NISA accepted.

Prices subject to change 


\section{English for the Teacher}

\section{A language development}

\section{course}

\section{Mary Spratt}

English for the Teacher is designed to help teachers to improve their language ability for a number of purposes - using English in the classroom, making professional contacts, studying the teaching of English and discussions with colleagues and students.

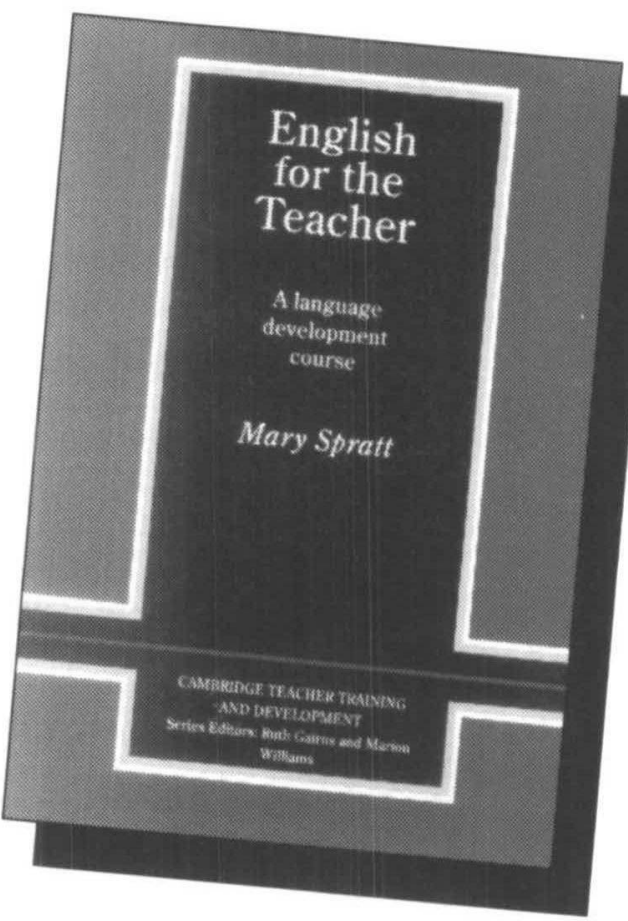

- A short introduction for users explains the basic principles underlying the material

- Each unit focuses on a theme from the world of teaching

- Reading and listening texts are taken from a range of authentic sources

- The course provides opportunities for more general professional development and reflecting on issues in education.

For further information, please contact:

ELT Marketing, Cambridge University Press,

The Edinburgh Building, Shaftesbury Road,

Cambridge CB2 2RU

TELEPHONE: (O223) 325846/7 FAX: (0223) 325984 


\section{Cambridge University Press}
The Pitt Building
Trumpington Street
Cambridge

CB2 1RP

\author{
40 West 20th Street \\ New York \\ NY10011-4211 \\ USA
}
10 Stamford Road
Oakleigh
Melbourne 3166

Australia

Printed in Great Britain at the University Press, Cambridge 


\section{language teaching}

The international abstracting journal for language teachers and applied linguists

July 1994 Volume 27 no 3

\section{Contents}

Review of research Richard Johnstone on research on language learning and teaching, 1993

State of the art Martin Cortazzi on narrative analysis

Abstracts

Language learning and teaching -

245-304 theory and practice

$305-323$

Teaching particular languages

$324-348$

Research in the supporting sciences

$349-352$

Language description and use

New books

Bibliographies

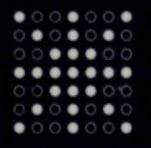

The British Council

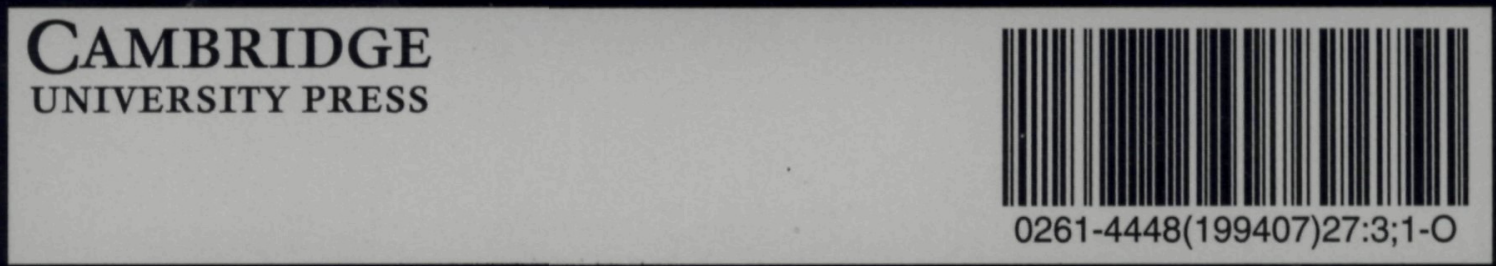

